\title{
Türkiye'de Yenilenebilir Enerji Tüketiminin İthalat Üzerindeki Etkisi
}

\author{
DOI: 10.26466/opus.521269 \\ *
}

\section{Erdal Arslan ${ }^{*}-$ Aysun Solak ${ }^{* *}$}

* Dr. Öğr. Üyesi, Selçuk Üniversitesi, İktisadi ve İdari Bilimler Fakültesi, Selçuklu / Konya/ Türkiye E-Posta: erdalarslan@selcuk.edu.tr ORCID: 0000-0003-4892-2963

** Yüksek Lisans Öğrencisi, Selçuk Üniversitesi, Selçuklu / Konya/ Türkiye E-Posta: aysunsolak111@gmail.com

ORCID: 0000-0001-9067-0654

Öz

Enerji ihtiyacının büyük bir kısmını ithalat yoluyla karşılayan ülkemizde büyük miktarlarda petrol, doğal gaz ağırlıkta olmak üzere fosil yakıtlar ithal edilmektedir. Enerji talebinin karşılanmasında ithalat oranının yüksek düzeyde seyretmesi, dışa bağımlılığın artmasına neden olmakta ve bu durum ise cari dengenin bozulmasinda en önemli etken konumuna gelmektedir. Dolayısıyla enerji talebinin karşılanmasında ithalat oranlarının düşürülmesi adına atılacak adımlar, yapılacak yatırımlar önem arz etmektedir. Bu çalışmanın amacı, Türkiye'de yenilenebilir enerji tüketiminin ithalat üzerindeki etkisinin araştırlmasıdır. 1984-2017 yıllarına ait verilerinin VAR analizi ile test edildiği çalışmada, ilk aşamada, serilerin durağanlıkları Augmented Dickey Fuller (ADF) Testi ile test edilmiştir. Seriler düzeyde birim kök içerdikleri için, serilerin birinci farkları alınmıştır. Yapılan Johansen Eş Bütünleşme testi sonucuna göre, değişkenler arasında uzun dönemli bir bağlantı bulunmamaktadır. Etki-Tepki fonksiyonlarl, yenilenebilir enerji tüketimindeki artışın ithalatı da arttırdığını göstermiştir. Sonuç olarak, belirli bir düzeyde dışarıdan transfer edilen yenilenebilir enerji teknolojileri bu artışa neden olsa da, son dönemlerde yürütülen çalışmalar ve yapılan önemli yatırımlar, teknoloji transferinin azalarak yenilenebilir enerji alanında yerli üretimin ön plana çıkmaya başladı̆̆ı söylenebilir.

Anahtar Kelimeler: Yenilenebilir enerji, Yenilenebilir enerji tüketimi, İthalat 


\title{
The Effect of Renewable Energy Consumption on Import in Turkey
}

\begin{abstract}
In Turkey, where a large part of the energy demand is met by imports, fossil fuels are imported with large amounts of oil and natural gas. The fact that the import rate is at a high level in meeting the energy demand causes an increase in foreign dependency and this situation becomes the most important factor in the deterioration of the current account balance. Therefore, the steps to be taken in order to reduce the import rates and the investments to be made in meeting the energy demand are important. The aim of this study is to investigate the effect of renewable energy consumption on the import. In the study in which the data for the years 1984-2017 were tested by VAR analysis, firstly, the stationals of the series were tested by Augmented Dickey Fuller ( $A D F)$ Test. In the first part of the study, the stationals of the series were tested with Augmented Dickey Fuller (ADF) Test. Since the series contains unit roots at the level, the first differences of the series are taken. According to the results of the Johansen cointegration test, there is no long-term connection between the variables. Reaction-Response functions showed that the increase in renewable energy consumption also increased imports. As a result, although renewable energy technologies, which were transferred from outside to a certain extent, led to this increase, it can be said that the recent studies and important investments made, and the decrease in technology transfer, domestic production started to come to the fore in the field of renewable energy.
\end{abstract}

Keywords Renewable energy, Renewable energy consumption, Import 


\section{Giriş}

Enerji, sanayileşme sürecinde bir itici güç ve sanayinin ilerlemesinde lokomotif olmuştur. Buradan hareketle enerjinin elde ediliş serüveni incelendiğinde; odunun yakılmasından başlayıp kömür ve daha sonra da petrole geçiş ile devam eden süreçte her yeni dönemde yeni bir enerji ham maddesi yükselişe geçmiştir. Ham maddesi değişse de enerjiye olan ihtiyaç artarak devamlılık göstermiştir.

Yaşamsal faaliyetlerin devam ettirilebilmesi ve üretimin temel girdisi olarak enerjiye olan talep artarak devam etmektedir. Ekonomik kalkınma ve büyümenin temel itici gücü enerjidir. Dolayısıyla ekonomik büyüme, kalkınmanın ve toplumsal gelişmelerin devamlılığının sağlanmasında enerji önemli bir yere sahiptir (Bilginoğulu ve Dumrul, 2012). Yaşanan teknolojik gelişmeler, refah seviyesindeki artış, artan nüfus ve şehirleşme, sanayileşme dolayısıyla artan üretim ve özellikle hızla büyüyen gelişmekte olan ekonomiler nedeniyle küresel enerji tüketimi de artış göstermektedir. Dolayısıyla küresel refah arttıkça enerji talebi de artmaktadır. Diğer yandan enerji tüketimi, ekonomik gelişmenin ve sosyal refahın en önemli göstergelerinden biri olarak kabul edilmektedir. Yapılan pek çok çalışmada, ülkelerin kalkınması ve gelişmişlik düzeyi ile enerji tüketiminin arasında doğru yönde bir ilişki olduğu görülmektedir.

Ekonomilerin sürekliliğinin sağlanması ve günlük hayatın devamlılığ1 için elzem olan enerji, kaynakları bakımından genel olarak iki grupta sinıflandırılmaktadır. Bu kaynaklar; yenilenebilir enerji kaynakları ve yenilenemeyen/ tükenebilir enerji kaynaklarıdır. Yenilenebilir enerjiden kasıt, bu enerjinin yeniden tekrarlanarak kullanılmasını ifade etmektedir. Kisa sürede yerine konulabilmektedir. Küresel ekonomilerin çoğunlukla kullandıkları yenilenebilir enerji kaynakları; hidrolik enerji, jeotermal enerji, biyokütle enerjisi, güneş enerjisi ve rüzgâr enerjisinden oluşmaktadır. Tükenebilir enerjiyi kullanıldığı takdirde kısa sürede yerine konulamayan enerji olarak tanımlanabilir. Bu grubu ise genel olarak; petrol, doğalgaz ve kömür gibi hidrokarbon barındıran fosil yakıtlar oluşturmaktadır (www.enerjibes.com,2018). Günümüzde dünya genelinde kullanımda olan temel enerji kaynakları ise fosil yakıtlar, nükleer yakıtlar ve hidrolik kaynaklardır ve fosil yakıtlar küresel enerji ihtiyacının büyük bir kısmının karşılandığı kaynaklardır. 
Kullanımda birinci sırada olan enerji kaynaklarından fosil yakıt rezervlerinin coğrafi dağılımı incelendiğinde; enerji kaynak rezervlerinin belli başlı bölgelere yoğunlaşmış durumda olduğu görülmektedir. Enerji kaynaklarının dengeli bir dağılım göstermemesi pek çok ülkenin enerji kaynakları açısından fakir olduğuna işaret etmektedir. Fosil yakıt kaynağ bulunmayan veya yeterli seviyede rezerve sahip olmayan bu ülkeler için enerjiye ulaşım sorunu yaşanmasına neden olmaktadır. Enerjiye ulaşımın sorunuyla karşı karşıya kalan bu ülkeler, hızla artan enerji ihtiyaçlarını yüksek miktarlarda enerji kaynağı ithalatı yaparak dış kaynaklardan karşılamak zorunda kalmaktadırlar. Bu durum enerji ithalatçısı konumuna gelen ülkelerin bütçesinde enerjinin yüksek bir paya sahip olması anlamına gelmektedir. Dolayısıyla da bir anlamda ülkenin ekonomik büyümesi ve kalkınması da dış kaynaklara bağımlı demektir. Bu bağlamda yüksek oranda enerji kaynağı ithal eden ve enerjide dişa bağımlı ülkeler için; fosil yakıtların arzında yaşanacak herhangi bir daralma, kıtlık enerji fiyatlarında artışa neden olacaktır ve enerji fiyatlarında meydana gelecek herhangi bir artış enerji ithalatçısı ülkelerin cari dengesini olumsuz etkileyecektir. Bu açıdan bakıldığında ülkelerin enerji bağımlılığı ülke ekonomisine büyük bir yük oluşturarak ekonomilerinin baskı altında kalmasına neden olmaktadır.

1973 ve 1974 yıllarında yaşanan petrol krizleri nedeniyle enerji arzındaki daralma, enerji ve enerji arzı güvenliğinin/ sürekliliğinin önemini ortaya çıkarmış ve dünyayı alternatif enerji kaynakları arayışına yöneltmiştir. Öte yandan enerji arzı güvenliği sorunun yanı sıra fosil yakıtların neden olduğu iklim değişikliği, yüksek maliyet gibi nedenlerle sürdürülemez nitelikte olması fosil yakıtların yapısı gereği yenilenemez olması, dengesiz dağılımı ve sinırlı rezervleri bulunması nedenleriyle uzun vadede enerji talebini karşılamada yeterli olmayacağı düşünülmektedir. Geride bırakılan yıllar içerisinde ülkeler, belirtilen sorunlar nedeniyle alternatif enerji kaynağı arayışına girmişler ve enerji kaynaklarının çeşitlendirilmesine yönelik politikalar üretmeye çalışmışlardır. Bu süreçte yenilebilir enerji kaynaklarının kullanıma kazandırılmasına yönelik çalışmalara ağırlık vermişlerdir ve 2000'li yıllar alternatif enerji kaynaklarına verilen önemin ve yapılan yatırımların yükselişe geçtiği yıllar olmuştur. Günümüzdeyse birçok ülkede bu yönde 
önemli gelişmeler yaşanmıştır ve bu ülkelerin enerji taleplerinin önemli bir kısmı yenilenebilir enerji kaynaklarından karşılanmaktadır.

Günümüzde enerji artık uluslararası arenada rekabet gücü, siyasi ve ekonomik üstünlüğün en önemli unsurudur. Dolayısıyla enerji arzı güvenliği, sürdürülebilirliği ve erişim kolaylığının sağlanmasının önemi ülkeler için öncelikli bir durumu ifade etmektedir. Yenilenebilir enerji kaynaklarına yönelmenin ve kullanımının arttırılması, Türkiye gibi enerji ithalatçısı, gelişmekte olan ülkeler için çok daha ayrı bir önemi vardır. Yerli kaynakların kullanımının arttırılması enerji ithalatçısı ülkelerin öncelikle ve en önemlisi enerji bağımlılığını azaltması, milli gelirde ve istihdam oranlarında artış, yeni yatırım alanları, düşük ithalat oranı, enerji arzı güvenliği, enerji kaynağı çeşitliliği, çevresel katkılar gibi pek çok konuda ülke ekonomisine katkı sağlayacaktır. Yenilenebilir enerji kaynaklarının kullanımının arttırılmasına yönelik teknolojilerinin geliştirilmesi ülkelerin sürdürülebilir ekonomik gelişimi için önem arz etmektedir.

Çalışmanın amacı, Türkiye' de 1984-2017 yılları için yenilenebilir enerji tüketiminin ithalat üzerindeki etkisinin incelenmesidir. Bu kapsamda VAR analiz modeli kullanılarak değişkenler arasındaki söz konusu ilişki test edilmiştir.

Bu çerçevede, çalışmanın ikinci bölümünde bu alanda yapılan çalışmalara ilişkin literatür taraması verilmiştir. Çalışmanın üçüncü bölümünde dünyanın enerji görünümüne yer verilirken, dördüncü bölümde Türkiye'nin enerji durumu ele alınmıştır. Beşinci bölümde, çalışmanın yöntemine, altıncı bölümünde ise Türkiye'de yenilenebilir enerji tüketiminin ithalat üzerine etkisine ilişkin araştırma bulgularına yer verilmiştir. Son bölümde ise araştırmanın sonuçları ve değerlendirmesi sunulmuştur.

\section{Literatür Değerlendirmesi}

Literatürde yenilenebilir enerji tüketiminin dış ticaret üzerindeki etkisini ele alan çalışmalar sınırlı sayıda olup, daha çok, enerji tüketimi, ekonomik büyüme, diş ticaret ve cari açık ilişkisinin incelenmesi üzerine çalışmalar bulunmaktadır. Bu çalışma ise, seçilen değişkenler, kullanılan teknikler ve kapsadı̆̆ 1 dönemler itibariyle literatür özeti verilen Tablo 1'deki çalışmalardan farklılaşmaktadır. Bu kapsamda, araştırma konusu kapsamındaki çalışmalara ilişkin literatür özeti aşağıdaki gibidir: 
Apergis ve Payne (2010) çalışmalarında 1992-2007 dönemi için Avrasya'daki 13 ülke için yenilenebilir enerji tüketimi ile ekonomik büyüme arasındaki nedensellik ilişkisini incelemişlerdir. Heterojen panel eş bütünleşme testi, reel GSYİH, yenilenebilir enerji tüketimi, reel brüt sabit sermaye oluşumu ve işgücü arasındaki uzun vadeli bir denge ilişkisini ortaya koymuşlardır. Hata düzeltme modellerinden elde ettikleri sonuç ise hem kısa vadede hem de uzun vadede yenilenebilir enerji tüketimi ile ekonomik büyüme arasındaki iki yönlü nedensellik göstermektedir. Elde ettikleri bulgulara göre yenilenebilir enerji tüketimi ve ekonomik büyüme arasındaki karşılıklı bağımlı ilişkinin geri besleme hipotezine destek vermektedir.

Yanar ve Kerimoğlu (2011) çalışmalarında enerji tüketimi 1975-2009 yılları arasında Türkiye' de enerji tüketimi, ekonomik büyüme ve cari açık ilişkisini eş bütünleşme testi ile analiz etmişlerdir. Johansen eş bütünleşme analizi ile enerji tüketimi, ekonomik büyüme ve cari açık arasında uzun dönemli biri ilişki olduğu belirlenmiş vektör hata düzeltme modeli ile büyüme arttıkça enerji tüketiminde artış olacağı, enerji tüketimindeki artışsa cari açığı arttırıcı etki yapacağı sonucuna ulaşmışlardır. Nedenselliğin yönüyse enerji tüketiminden büyümeye doğru güçlü bir ilişki bulunurken, büyüme ile cari açık arasında çift yönlü ancak zayıf bir ilişki bulunmaktadır.

Bilginoğlu ve Dumrul (2012) çalışmalarında Türkiye ekonomisinin enerji bağımlılığının belirleyicileri Johansen- Juselius eş bütünleşme testi ile analiz etmişlerdir. Analizin sonucunda enerji yoğunluğunun, gayrisafi milli hasılanın ve konutlardaki enerji tüketiminin enerji bağımlılığını pozitif yönde etkilediğini görmüşlerdir.

Demir (2013) çalışmasında VAR analizi kapsamında eş bütünleşme, hata düzeltme modeli ve Granger nedensellik testiyle sanayi üretimi, cari açık ve enerji ithalatı arasındaki ilişkinin niteliğini ve yönünü test etmiş ve analizin sonucuna göre Türkiye'de nedenselliğin yönü sanayi üretim endeksi ve enerji ithalatından cari açığa doğru tek yönlü nedensellik şeklindedir.

Apergis ve Danuletiu (2014) çalışmalarında yenilenebilir enerji ile ekonomik büyüme arasındaki ilişkiyi 80 ülke için Canning ve Pendroni(2008) uzun dönem nedensellik testi ile test etmişler ve uzun dönemli bir neden- 
sellik olduğu sonucuna ulaşmışlardır. Yenilenebilir enerji tüketimi ve ekonomik büyüme arasındaki karşılıklı bağımlılık olduğunu ve yenilenebilir enerjinin ekonomik büyüme için önemli olduğu yine benzer şekilde ekonomik büyümenin daha çok yenilenebilir enerji kullanımına teşvik ettiği sonucuna varmışlardır.

Uysal vd. (2015) çalışmaların 1980-2012 yıllarına ait veriler kullanılarak büyüme, enerji tüketimi ve cari açık verileri kullanılarak VAR modeli kullanılarak, Johansen eş bütünleşme analizi uygulamışlardır. Buna ek olarak değişkenlere etki-tepki analizi ve varyans ayrıştırması yapmışlar ve analizin sonucunda değişkenlerin uzun dönemde birlikte hareket ettiği sonucuna ulaşmışlardır.

Sancar ve Polat ( 2015) çalışmalarında Türkiye'de ekonomik büyüme, enerji tüketimi ve enerji ithalatı arasındaki nedensellik ilişkisini 1984-2011 dönemi için zaman serisi yöntemi ile test etmişler ve GSYH'nın bağımlı değişken, enerji tüketimi ve ithalatın açılayıcı değişken olduğu modelin birim kök testi sonuçlarına göre seriler I(1) seviyesinde durağandır. Johansen eş bütünleşme testinin sonuçlarına göre ise değişkenler uzun dönemde birlikte hareket etmektedir. Son olarak uyguladıkları nedensellik testi sonuçlarına göre uzun dönemde enerji tüketimi ve ithalattan GSYH'ya doğru tek yönlü bir nedensellik ilişkisi bulunurken, kısa dönemde enerji tüketimi ve ithalattan GSYH'ya doğru tek yönlü; enerji tüketimi ile ithalat arasındaysa çift yönlü nedensellik ilişkisi bulunduğunu tespit etmişlerdir.

Bhattacharya vd.(2016) yürüttükleri çalışmalarında 1991-2012 yıllarına ait verilerle seçtikleri 38 yenilenebilir enerji kullanan ülkelerin ekonomik büyüme sürecine etkisini incelemek için Ernst\&Young Global Limited tarafından geliştirilen Yenilenebilir Enerji Ülke Çekicilik Endeksi'ni kullanmışlardır. Uyguladıkları panel tahmin tekniğinin sonucunda ise söz konusu ülkeler arasında kesitsel bağımlılık ve heterojenlik oluşturduğunu bulmuşlardır. Uzun vadeli çıktı esnekliklerinden elde ettikleri bulgular; yenilenebilir enerji tüketiminin seçtikleri ülkelerin \%57'si için ekonomik çıktı üzerinden önemli bir pozitif etkisinin olduğu yönündedir. Dayanıklılık içinse uzun vadeli çıtı esnekliklerinin zaman serisi analizi gerçekleştirmişlerdir.

Doğan ve Gürbüz (2017) çalışmalarında enerji giderleri ile dış ticaret açığı arasındaki ilişkiyi doğrusal olmayan ekonometrik modellerle ele 
almışlar ve 2002:1-2015:12 dönemini kapsayan verileri ise TÜiK ve MB (TCMB)'dan almışlardır. Doğrusal olmayan Granger nedensellik testinde ulaştıkları sonuç ise enerji giderleri ve dış ticaret açı̆̆ı değişkenlerinin arasında çift yönlü bir nedensellik olduğu yönündedir.

Khobai vd. (2017) çalışmalarında 1990-2013 yılları için Brics ülkelerindeki enerji tüketimi ve ekonomik büyüme arasındaki uzun dönemli ilişkiyi ve nedenselliği incelemişlerdir. Analizlerinde değişkenler arasındaki eş bütünleşme ilişkisini Pedroni paneli eş bütünleşme yöntemiyle, nedensellik ilişkisini de Pair-wise Granger nedensellik tekniklerini kullanmışlardır. Çalışmalarının sonucu ise, Brics ülkelerinde ekonomik büyüme, enerji tüketimi, istihdam ve dış ticaret açı̆̆ı arasında uzun dönemli bir ilişki olduğu yönündedir. Buna ek olarak ekonomik büyümeden enerji tüketimine doğru tek yönlü bir nedensellik olduğunu da tespit etmişlerdir.

Khobai vd. (2017) yürüttükleri araştırmada 1990-2014 yılları için Güney Afrika'da yenilenebilir enerji tüketimi ve işsizlik arasındaki ilişkiyi incelemişlerdir. Çalışmalarında yenilenebilir enerji tüketiminin uzun vadede ve kısa vadede işsizliğe etkilerini test etmek için Otoregresif Dağıtılmış Lag(ARDL)modelini kullanmışlardır. Elde edilen sonuç ise yenilenebilir enerji tüketiminin uzun vadede işsizlik üzerinde negatif ve anlamlı bir etkisin olduğudur. Buna ek olarak, kısa vadede değişkenlerin önemsiz bir ilişkisi olduğu sonucunu da elde etmişlerdir. Çalışmanın sonunda vardıkları yargı ise istihdam seviyelerini yükseltmek için yenilenebilir enerji üretim ve tüketiminde artışa gidilmesi gerektiği yönündedir.

Brini vd. (2017) çalışmalarında Tunus için 1980-2011 dönemi verilerini kullanarak enerji tüketimi, uluslararası ticaret, petrol fiyatı ve ekonomik büyüme arasındaki ilişkiyi eş bütünleşme için sınır testi yaklaşımı ve ARDL yöntemini kullanarak analiz etmişlerdir. Analizlerinin sonucu ise kısa vadede yenilenebilir enerji tüketimi ile uluslararası ticaret arasında çift yönlü bir ilişki bulunurken, yenilenebilir enerji ile petrol fiyatları arasinda tek yönlü bir ilişki bulunmuştur.

Önder ve Polat (2018) yürüttükleri çalışmalarında 35 OECD ülkesi için 1996-2014 yıllarına dair verileri kullanarak dengeli panel ile analiz ederek emek, sermaye ve yenilenebilir enerjinin GSYİH üzerinde pozitif bir etkiye sahip olduğu sonucuna ulaşmışlardır. Sırasıyla en büyük etki sermaye, emek ve yenilenebilir enerji şeklinde olmuştur. Çalışmalarında 
yenilenebilir ve yenilenemez enerji kaynaklarını ayrı ayrı teste tabi tutmuşlar ve yenilenebilir enerji kaynaklarının GSYİH'ya etkisinin pozitif, yenilenemez enerji kaynaklarının ise negatif bir etkisinin olduğu sonucuna ulaşmışlardır.

Tablo 1. Literatür Özeti

\begin{tabular}{|c|c|c|c|}
\hline $\begin{array}{l}\text { Yazar/ } \\
\text { Y1l }\end{array}$ & Yöntem & Konu & Sonuç \\
\hline $\begin{array}{l}\text { Yanar } \\
\text { ve Keri- } \\
\text { moğlu } \\
(2011)\end{array}$ & $\begin{array}{l}\text { Johansen Eş } \\
\text { Bütünleşme + } \\
\text { Nedensellik } \\
\text { Testi }\end{array}$ & $\begin{array}{l}\text { Türkiye'de 1975- } \\
2009 \text { yılları arasında } \\
\text { enerji tüketimi, } \\
\text { ekonomik büyüme } \\
\text { ve cari açı } \\
\text { ilişkisinin incelen- } \\
\text { mesi. }\end{array}$ & $\begin{array}{l}\text { Johansen eş bütünleşme analiziyle } \\
\text { değişkenler arasında uzun dönemli } \\
\text { bir ilişki olduğu belirlenmiştir. } \\
\text { Nedensellik testiyle enerji tüketimin- } \\
\text { den büyümeye doğru güçlü bir ilişki } \\
\text { bulunurken, büyüme ile cari açık } \\
\text { arasında çift yönlü ancak zayıf bir } \\
\text { ilişki bulunmaktadır. }\end{array}$ \\
\hline $\begin{array}{l}\text { Demir } \\
(2013)\end{array}$ & $\begin{array}{l}\text { VAR Analizi } \\
+ \\
\text { Granger } \\
\text { Nedensellik }\end{array}$ & $\begin{array}{l}\text { Sanayi üretimi, cari } \\
\text { açı ve enerji ithalatı } \\
\text { arasındaki ilişkinin } \\
\text { niteliği ve yönü }\end{array}$ & $\begin{array}{l}\text { Nedenselliğin yönü sanayi üretim en- } \\
\text { deksi ve enerji ithalatından cari açığa } \\
\text { doğru tek yönlüdür. }\end{array}$ \\
\hline $\begin{array}{l}\text { Uysal } \\
\text { vd. } \\
(2015)\end{array}$ & $\begin{array}{l}\text { VAR Analizi } \\
+ \\
\text { Johansen Eş } \\
\text { Bütünleşme } \\
\end{array}$ & $\begin{array}{l}\text { 1980-2012 yıllarına } \\
\text { ait büyüme, enerji } \\
\text { tüketimi ve cari açık } \\
\text { verilerinin analizi }\end{array}$ & $\begin{array}{l}\text { Değişkenler uzun dönemde birlikte } \\
\text { hareket etmektedir. }\end{array}$ \\
\hline $\begin{array}{l}\text { Sancar } \\
\text { ve Polat } \\
\text { (2015) }\end{array}$ & $\begin{array}{l}\text { Johansen Eş } \\
\text { Bütünleşme } \\
+ \\
\text { Nedensellik } \\
\text { Testi }\end{array}$ & $\begin{array}{l}\text { Türkiye'de 1984- } \\
2011 \text { yıllarına ait dö- } \\
\text { nemde ekonomik } \\
\text { büyüme, enerji tü- } \\
\text { ketimi ve enerji } \\
\text { ithalatı arasındaki } \\
\text { nedensellik ilişkisi }\end{array}$ & $\begin{array}{l}\text { Değişkenler uzun dönemde birlikte } \\
\text { hareket etmektedir. Uzun dönemde } \\
\text { enerji tüketimi ve ithalattan } \\
\text { GSYİH'ye doğru tek yönlü; kısa dö- } \\
\text { nemde enerji tüketimi ve ithalattan } \\
\text { GSYİH'ye doğru tek yönlü; enerji tü- } \\
\text { ketimi ile ithalat arasındaysa çift } \\
\text { yönlü nedensellik ilişkisi } \\
\text { bulmuşlardır. }\end{array}$ \\
\hline $\begin{array}{l}\text { Doğan } \\
\text { ve } \\
\text { Gürbüz } \\
\text { (2017) }\end{array}$ & $\begin{array}{l}\text { Granger } \\
\text { Nedensellik }\end{array}$ & $\begin{array}{l}\text { 2002:1-2015:12 dö- } \\
\text { nemine ait verilerle } \\
\text { Enerji giderleri ile } \\
\text { dış ticaret açı̆̆1 } \\
\text { arasındaki ilişki }\end{array}$ & $\begin{array}{l}\text { Enerji giderleri ve dış ticaret açı̆̆ı } \\
\text { değişkenlerinin arasında çift yönlü bir } \\
\text { nedensellik olduğu yönündedir. }\end{array}$ \\
\hline $\begin{array}{l}\text { Brini } \\
\text { vd. } \\
(2017)\end{array}$ & $\begin{array}{l}\text { ARDL Yönt- } \\
\text { emi }\end{array}$ & $\begin{array}{l}\text { 1980-2011 ait ver- } \\
\text { ilerle Tunus'un en- } \\
\text { erji tüketimi, } \\
\text { uluslararası ticaret, } \\
\text { petrol fiyatı ve } \\
\text { ekonomik büyüme } \\
\text { arasındaki ilişki }\end{array}$ & $\begin{array}{l}\text { Kısa vadede yenilenebilir enerji tü- } \\
\text { ketimi ile uluslararası ticaret arasında } \\
\text { çft yönlü bir ilişki; yenilenebilir enerji } \\
\text { ile petrol fiyatları arasında tek yönlü } \\
\text { bir ilişki bulunmuştur. }\end{array}$ \\
\hline
\end{tabular}


Erdoğan vd. (2018) çalışmalarında, Türkiye'de yenilenebilir enerji üretimiyle ekonomik büyüme(GSYH) arasındaki ilişkiyi Johansen eş bütünleşme testi ve VECM nedenselliği ile test edilmiştir. Test sonuçları, ekonomik büyümenin yenilenebilir enerji üretiminin uzun dönemde nedeni olduğu ve bu iki değişkenin eş bütünleşik olduğunu göstermiştir.

Durğun ve Durğun (2018) çalışmalarında 1980-2015 dönemine ait kişi başına gayrisafi yurtiçi hasıla ile kişi başına yenilenebilir enerji tüketimi (hidroelektrik dahil) arasındaki nedensellik ilişkisi zaman serisi analiziyle incelemişlerdir. ADF ve Zivot- Andrews birim kök testlerini uygulamışlar ve düzey değerlerinde birim kök içerdikleri sonucuna varmışlar ve seriler 1. farkları alındığında durağanlaştığı görülmüştür. ARDL sınır testi sonuçlarıysa serilerin $\% 5$ anlamlılık düzeyinde eş bütünleşik olduğu yönünde olmuştur. Eş bütünleşik serilere Toda-Yamamoto nedensellik testi uygulanarak yenilenebilir enerji tüketiminden büyümeye doğru tek yönlü nedensellik olduğu bulmuşlar ve yenilenebilir enerji tüketimindeki artışların ekonomik büyüme sağlayacağı sonucuna ulaşmışlardır.

\section{Türkiye'nin Enerji Görünümü}

Büyüyen bir ekonomiye sahip Türkiye; enerji talebi sürekli artış gösteren, tükettiği enerjinin büyük bir kısmını ithalat yoluyla karşılama yoluna giden ve yenilenebilir enerji kaynakları bakımından yüksek potansiyele sahip bir ülkedir. Ancak, yenilenebilir enerji üretimi seviyesi oldukça düşük seviyededir. Yenilenebilir enerji kaynaklarının kullanılabilir hale getirilmesi uzun dönemde ülkemiz için oldukça önemlidir. Ülkemizde 2009 ve sonrasında yenilenebilir enerjide önemli gelişmeler yaşanmıştır.

Türkiye, birincil enerji ihtiyacının önemli bir kısmını doğal gaz ile karşılamaktadır. Doğal gazı ise kömür ve petrol takip etmektedir. Türkiye' de, kişi başına düşen ortalama enerji tüketim düzeyi İktisadi İşbirliği ve Kalkınma Teşkilatı (OECD) ülkelerinden azdır (www.setav.org,2018). Yine Türkiye OECD ülkelerinin arasında geçen son 15 yılda enerjiye olan talep artışının en hızlı gerçekleştiği ülke konumuna ulaşmıştır. Bu artışa rağmen Türkiye'nin enerji kullanımı hala düşük seyretmektedir. Türkiye'nin enerji talebindeki artış eğilimini sürdürmesi beklenmektedir (DEK-TMK,2018). 
BP'nin Dünya Enerji Görünümü Raporuna göre, 2016'da Türkiye'nin birincil enerji kaynaklarındaki tüketimi \%4.2 oranında artış gösterdi. Bu duruma göre küresel birincil enerji kaynaklarının \%1'ini Türkiye tarafından tüketilmektedir. Petrol tüketimi 2016 'da $\% 5,7$ artışla günlük 886 bin varil petrol tüketen Türkiye, küresel petrol tüketiminde $\% 0,9^{\prime}$ luk bir paya sahiptir (BP,2017). 2017'de 25,8 milyon ton ham petrol ve 16,8 milyon ton petrol ürünü ithalatı gerçekleştirilmiştir.

Grafik 1. Türkiye'nin Toplam Birincil Enerji Arzı, Nihai Enerji Tüketimi ve İthalatı 1990-2016

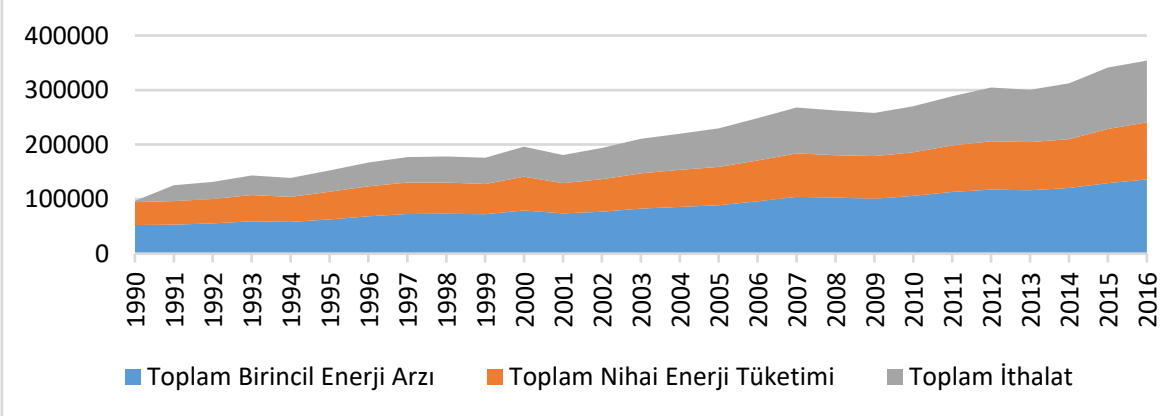

Kaynak: ETKB,2018

Türkiye'nin yıllar içerisinde toplam birincil enerji arzında artış yaşanmış olmasına rağmen enerji talebin artış hızının daha yüksek olduğu görülmektedir. Dolayısıyla enerji talebinin karşılanmasında yerli kaynakları yeterli olmayan Türkiye yıllar içerisinde enerji ithalatını arttırmıştır. Öncelikle petrol ve doğalgaz olmak üzere, ülkemizin enerji ithalatına olan bağımlılığı artarak devam etmektedir. Fosil yakıtlar açısından fakir olan Türkiye'nin, enerji talebini karşılamakta yerli kaynakları yetersiz kalmaktadır ve Türkiye'de toplam enerji talebinin ancak \%26'sı yerli kaynaklardan karşılanabilmektedir. Bu durum Türkiye'yi enerji ithalatçısı bir ülke konumuna getirmektedir. Türkiye'nin enerji talebini karşılaması; petrolün \%92'si, doğal gazın ise $\% 99^{\prime} u$ ithal edilmesine bağlı olarak diş kaynaklara bağımlılığ $\% 75$ oranındadır.

Aşağıda Grafik 2 ve 3 Türkiye'nin yerli kaynaklarından ürettiği ham petrol ve doğalgazın yıllar içerisindeki değişimini göstermektedir. 
Grafik 2. Türkiye'de Yıllara Göre Ham Petrol Üretimi (Milyon Varil)

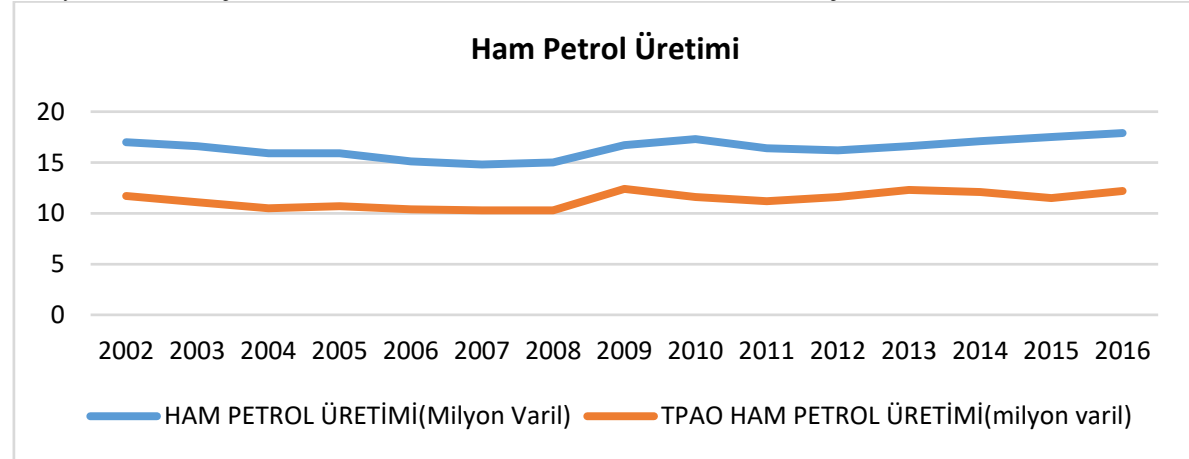

Kaynak:ETKB,2018(http://www.enerji.gov.tr/Resources/Sites/1/Pages/Sayi_15/mobile/index.html\#p=45)

\section{Grafik 3. Türkiye'de Yıllara Göre Doğalgaz Üretimi}

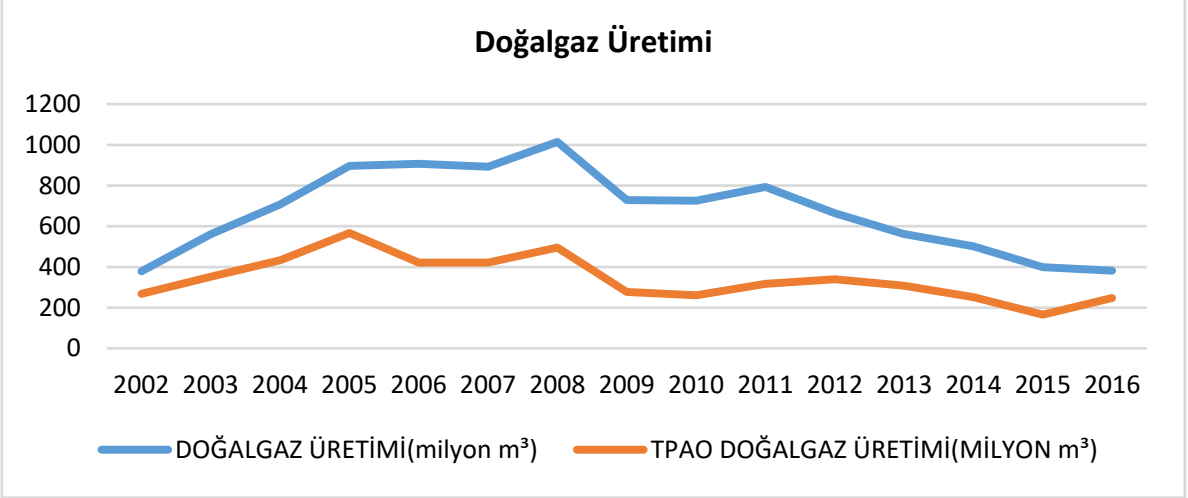

Kaynak:ETKB,2018(http://www.enerji.gov.tr/Resources/Sites/1/Pages/Sayi_15/mobile/index.html\#p=45)

Grafik 4. Türkiye'nin Havza Taşkömürü Üretimi 2000-2016

\section{Havza Toplamı(Ton)}

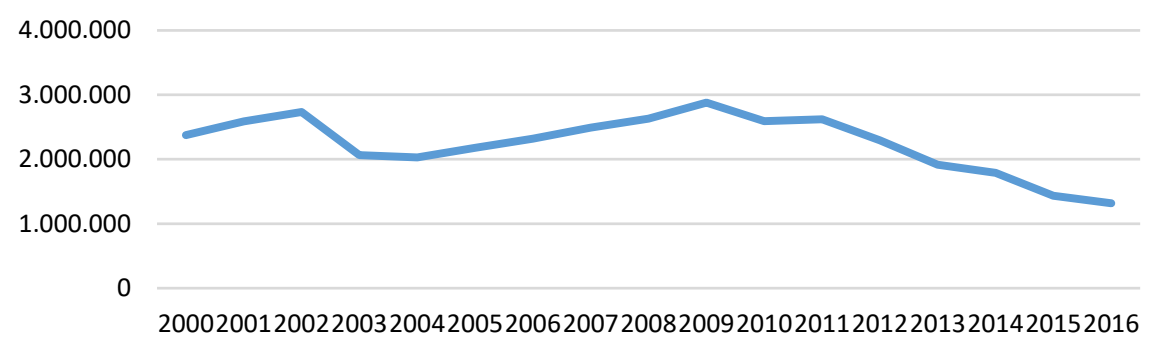

Kaynak:ETKB,TTK,2018(http://www.taskomuru.gov.tr/file/duyuru/TTKGM_Sektor_Raporu_2016.PDF 
Grafik 5. Türkiye'nin Yıllara Göre Kömür Üretimi (Bin TEP)

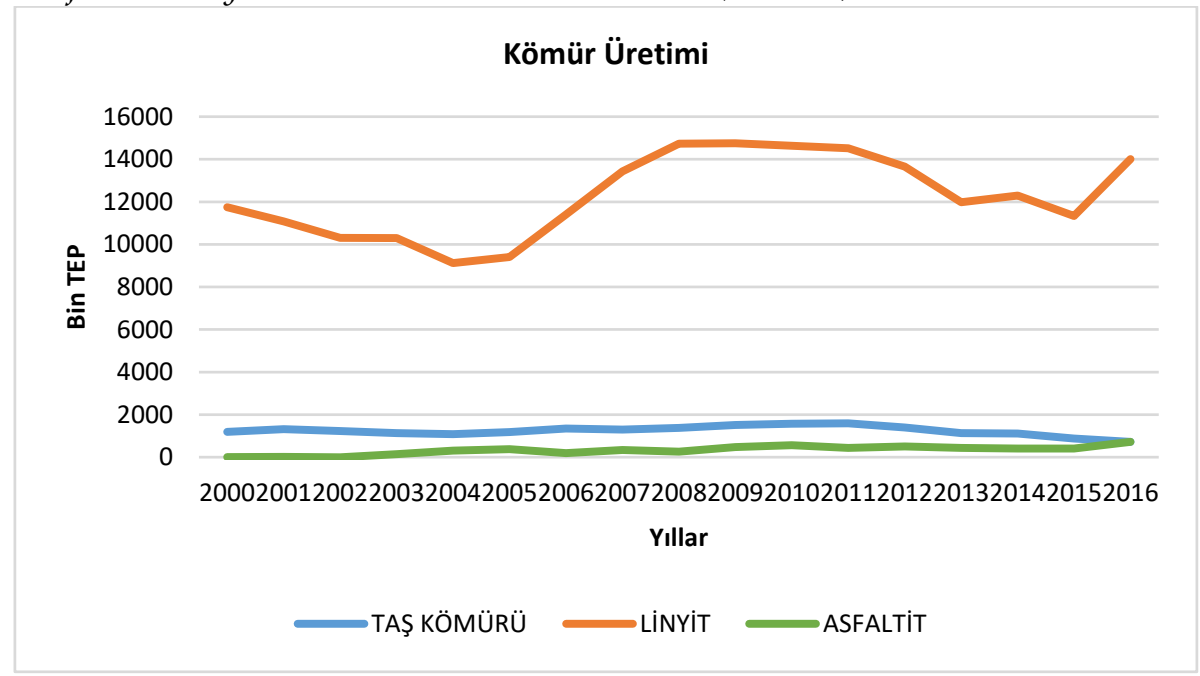

Kaynak: ETKB, Genel Enerji Denge Tabloları

Bir başka açıdan bakıldığında, enerji talebinin karşılanmasında büyük oranda dış kaynaklara bağımlı olan ülkemizde uygulanan enerji politikaları küresel enerji sektöründe yaşanan gelişmelerden büyük oranda etkilenmektedir. Bu durumda enerji piyasasında yaşanan her türlü gelişmeyi yakından takip etmek zorunda kalmaktadır. Enerji fiyatlarındaki her artış, ithalatçı konumdaki Türkiye'nin enerji ithalat bedelini yükselteceği için cari denge üzerinde de olumsuz etki yaratacaktır. Enerji arzı güvenliğinin nedeniyle enerji kaynak çeşitliliğine gidilmesi Türkiye'nin yerli ve yenilenebilir enerji kaynaklarına ilişkin girişim ve araştırmaları yürütmesi ve desteklemesi büyük bir önem arz etmektedir.

Türkiye coğrafi konumunun ve jeolojik yapısının bir getirisi olarak yenilenebilir enerji kaynaklarının çoğundan yararlanabilme fırsatına sahip bir ülkedir. Yenilenebilir enerji kaynakları çeşitlerinden hidrolik, rüzgâr, güneş, biokütle, jeotermal enerjisinin bulunduğu Türkiye' de 2017 yılı itibariyle yenilenebilir enerjinin payı $\% 45,48^{\prime}$ dir. Türkiye, yenilenebilir enerji kaynakları çeşitliliğinin potansiyeli bakımından $\mathrm{AB}$ ülkeleriyle kıyaslanacak olursa, özellikle hidrolik enerjisi açısından oldukça elverişlidir. Yenilenebilir enerji potansiyeli olmasına rağmen ülkemizde yenilenebilir enerji kaynaklarından yararlanma oranı düşüktür. 
Grafik 6. Türkiye'de Enerji Arzı Kaynak Dă̆ılımı, 1990-2016

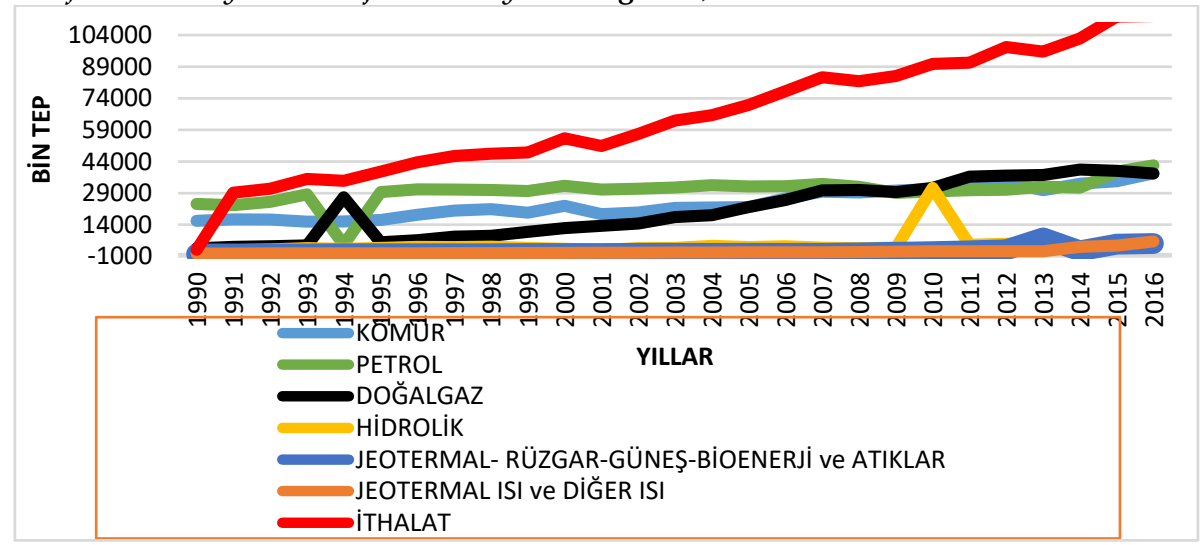

Kaynak: ETKB, Genel Enerji Denge Tablolar

Enerji ihtiyacını büyük oranda petrol ve doğalgazdan karşılayan Türkiye petrol ve doğalgazda dışa bağımlılı̆̆ı en üst düzeyde olan ülkelerin başında gelmektedir. Grafik 7 incelendiğinde Türkiye'de 2017 yılında elektrik üretiminin \%37'si doğalgaz, \%33'ü kömür, \%20'si hidrolik, \%6's1 rüzgâr, \%2'si jeotermal ve \%2'si diğer kaynaklardan elde edildiği görülmektedir

Grafik 7. 2017'de Türkiye'nin Elektrik Üretiminin Kaynakları Dağılımı

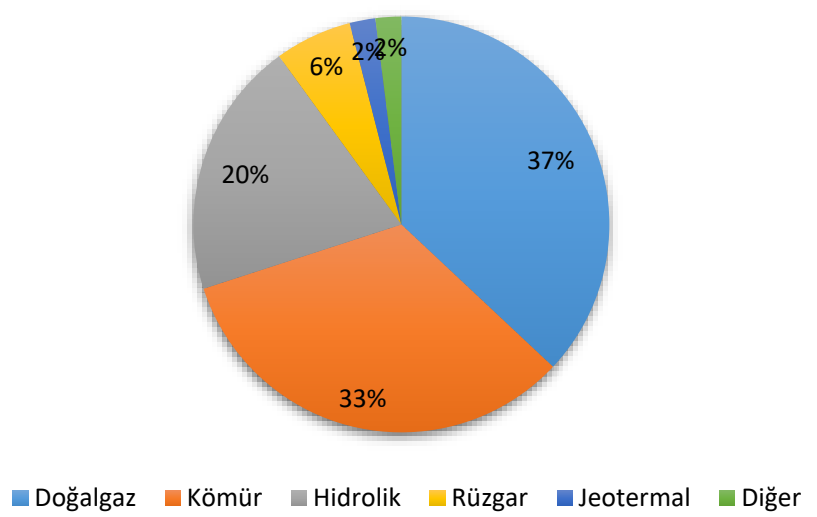

Kaynak: ETKB,2018 
Türkiye'nin kaynaklarına göre yenilenebilir enerji üretim miktarları Grafik 8'de gösterilmiştir.

Grafik 8. Türkiye'nin Kaynaklarına Göre Yenilenebilir Enerji Üretimi 1990-2016(Bin Tep)

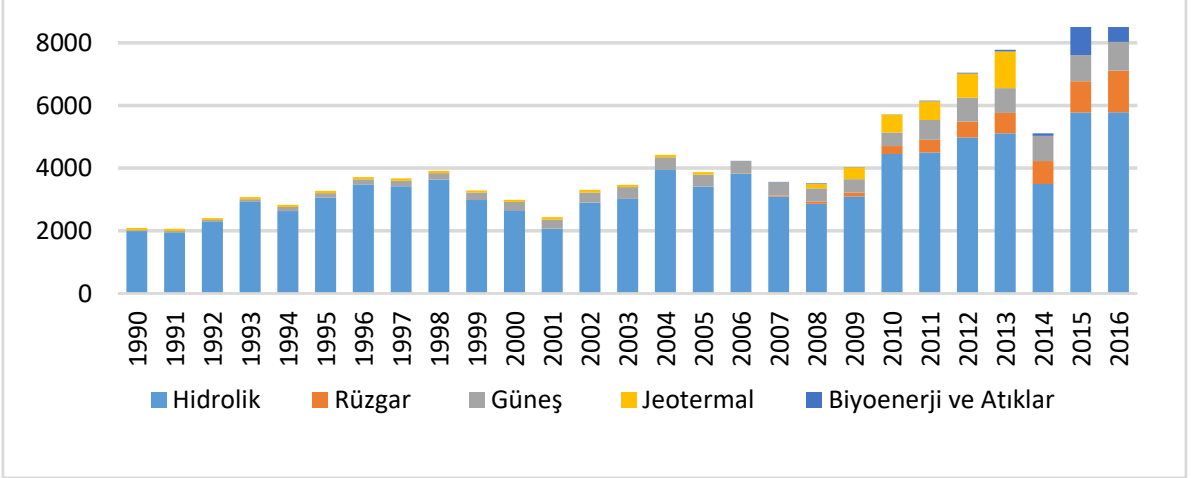

Kaynak: ETKB, Genel Enerji Denge Tabloları(Yazar tarafindan oluşturulmuştur.)

Türkiye, fosil yakıt kaynakları bakımından yeterli kaynakları olmayan ancak, yenilenebilir enerji kaynakları (güneş, rüzgâr, jeotermal) bakımından yüksek potansiyele sahip bir ülkedir. Ülkemizde bu kaynaklardan enerji üretimi söz konusu olduğunda, potansiyelinin çok altında bir enerji üretimi gerçekleştirmektedir.

Grafik 9'da, Türkiye'nin Kurulu gücününün yıllar içerisindeki değişimi verilmiştir.

\section{Grafik 9. Türkiye Kurulu Gücünün Yıllar İtibariyle Gelişimi}

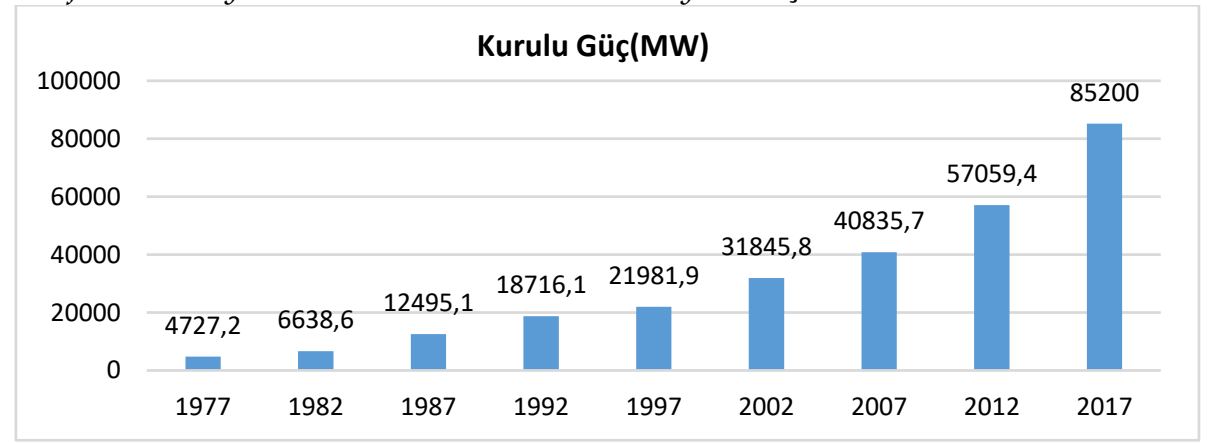

Kaynak: TEİA̧,2018 
Türkiye'nin kurulu güçte kullanılan enerji kaynaklarında yerli ve ithal kaynakların sahip olduğu oranlar ise Grafik 10' da verilmiştir.

\section{Grafik 10. Yerli ve İthal Kaynaklar Bazında Türkiye'nin Kurulu Gücü (\%)}

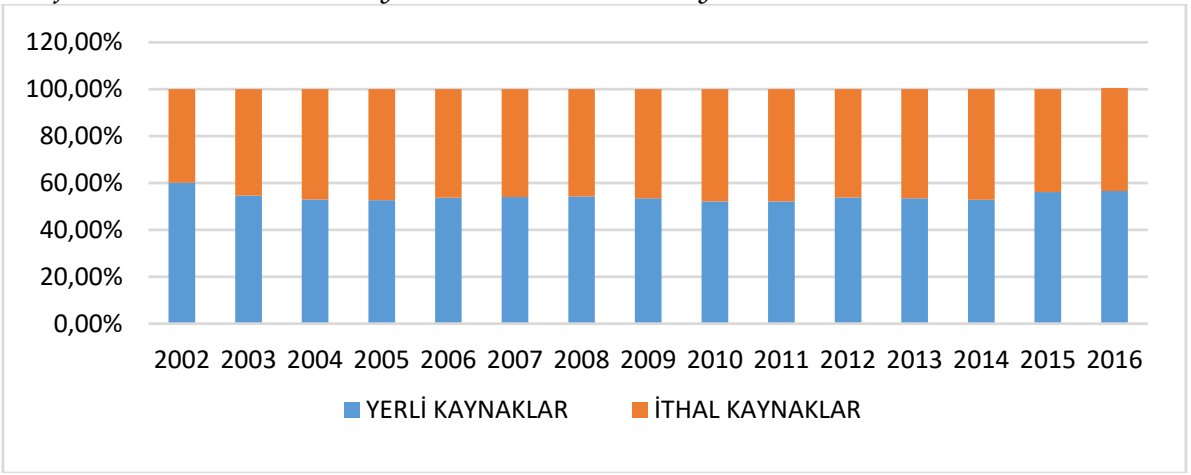

Kaynak: ETKB,2018

Grafik 11'de Türkiye'nin kurulu gücün kullanılan birincil enerji kaynaklarının 2007 ile 2017 yılındaki kullanımında gerçekleşen değişimi görülmektedir.

Grafik 11. 2007 ve 2017 Yılları İçin Birincil Enerji Kaynaklarına Göre Türkiye Kurulu Gücü $(M W)$

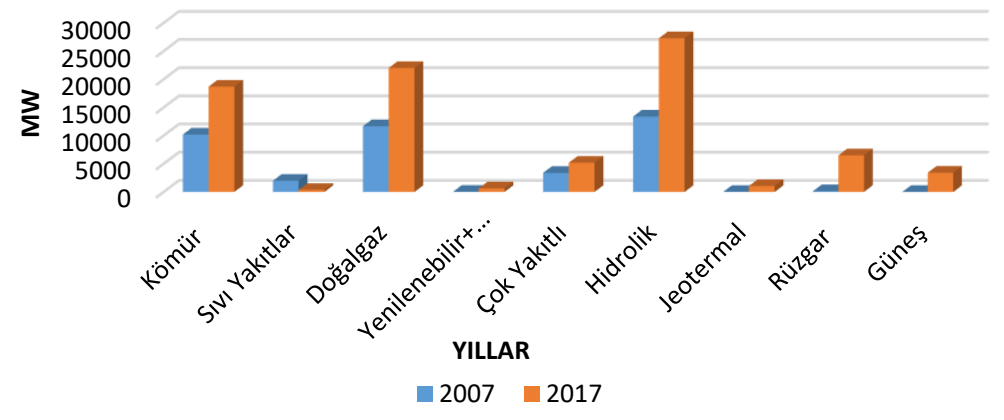

Kaynak: TEİŞ,2018. 
Aşağıdaki Grafik 12'de yenilenebilir enerji kaynaklarının Türkiye toplam kurulu gücü içerisindeki payının yıllar içerisindeki gelişimi verilmiştir.

Grafik 12. Yenilenebilir Kaynaklı Kurulu Gücün Türkiye Toplam Kurulu Gücü İ̧̧indeki Payinin Yallar İtibariyle Gelişimi (2000-2017)

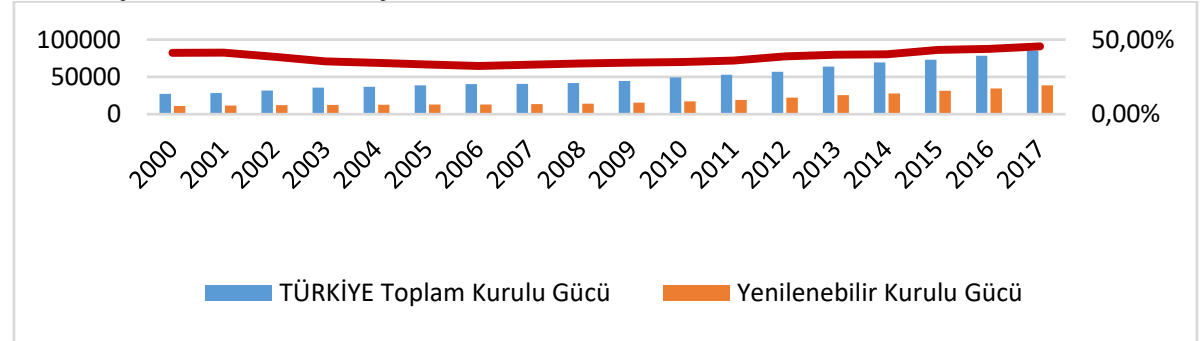

Kaynak: TEIAŞ,2018.

Grafik 12'de, 2000-2017 yılları arasında hem yenilenebilir kurulu güç hem de toplam kurulu güç içerisindeki enerji payında artış olduğu anlaşılmaktadır.

\section{Veri ve Ekonometrik Yöntem}

Türkiye ekonomisinde yenilenebilir enerji tüketiminin ithalat üzerindeki etkisinin araştırıldığı bu çalışmada, 1984-2017 dönemine ait yıllık veriler kullanılmış olup, kullanılan verilerin kaynakları Tablo 2'de verilmiştir.

Tablo 2. Veriler ve Kaynakları

\begin{tabular}{|l|l|}
\hline Değişkenler & Kaynak \\
\hline Yenilenebilir Enerji Tüketimi & BP \\
\hline İthalat & TÜIK \\
\hline
\end{tabular}

Tablo 2'de yer alan değişkenler arasındaki ilişkiyi belirlemek üzere yapılan ekonometrik analizlerde kullanılan teknikler aşağıdaki gibidir:

i. Birim Kök Testleri

ii. Johansen Eş Bütünleşme Testi

iii. Etki - Tepki Fonksiyonları

iv. VAR Analizi 


\section{Araştırma Bulguları}

Yenilenebilir enerji tüketimi ile ithalat arasında bir ilişkinin olup olmadığını belirlemek ve bir sahte regresyon probleminin ortaya çıkmasını engellemek üzere ilk olarak serilerin durağanlıkları Augmented Dickey Fuller (ADF) Testi ile sınanmış ve Tablo 3'de verilmiştir. Elde edilen sonuçlara göre her iki serinin de düzeyde birim kök içerdiklerini, ancak birinci farkları alındıktan sonraysa durağanlık problemi ortadan kalktığı görülmüştür.

\subsection{Birim kök testleri}

Yenilenebilir enerji tüketimine ilişkin birim kök testi sonuçları Tablo 3' de verilmiştir.

Tablo 3. ADF Birim Kök Testi Sonuçları (Yenilenebilir Enerji Tüketimi)

\begin{tabular}{|c|c|c|c|c|c|c|c|}
\hline \multicolumn{4}{|c|}{ Düzey } & \multicolumn{4}{|c|}{ 1. Fark } \\
\hline & & t-Statistic & Prob.* & & & t-Statistic & Prob. $^{*}$ \\
\hline \multicolumn{2}{|c|}{$\begin{array}{l}\text { Augmented } \\
\text { Dickey-Fuller } \\
\text { test statistic }\end{array}$} & 0.01145 & 0.9530 & \multicolumn{2}{|c|}{$\begin{array}{l}\text { Augmented } \\
\text { Dickey-Fuller } \\
\text { test statistic }\end{array}$} & -3.82502 & 0.0067 \\
\hline \multirow{3}{*}{$\begin{array}{l}\text { Test } \\
\text { critical } \\
\text { values: }\end{array}$} & $1 \%$ level & -364634 & & \multirow{3}{*}{$\begin{array}{l}\text { Test criti- } \\
\text { cal val- } \\
\text { ues: }\end{array}$} & $1 \%$ level & -3.66166 & \\
\hline & $5 \%$ level & -2.95402 & & & $5 \%$ level & -2.96041 & \\
\hline & $10 \%$ level & -2.61582 & & & $10 \%$ level & -2.61916 & \\
\hline \multicolumn{4}{|c|}{ *MacKinnon(1996) tek yönlü p-değerleri } & \multicolumn{4}{|c|}{${ }^{*}$ MacKinnon (1996) tek-yönlü p-değerleri } \\
\hline
\end{tabular}

Tablo 3'deki t istatistik değeri mutlak değer olarak \%1, \%5 ve \%10 anlamlılık düzeylerindeki kritik değerlerden küçük çıktığı için Yenilenebilir Enerji serisi düzeyde birim kök içermektedir. Bu nedenle serinin 1. Farkı alınarak yeniden durağanlık sınaması yapılmış ve elde edilen bulgular serinin 1. Farkında birim kök sorununun ortadan kalktığını göstermiştir.

İthalat serisi de yenilenebilir enerji serisinde olduğu gibi düzeyde birim kök içerdiği için 1 . Farkı alınarak yeniden durağanlık testine tabi tutulmuş ve sonuçlar Tablo 4 'te sunulmuştur. $t$ istatistik değeri mutlak değer olarak \%1, \%5 ve \%10 anlamlılık düzeylerindeki kritik değerlerden mutlak değer olarak yüksek çıktığı için ithalat serisi 1. Farkında durağan olduğu anlaşılmıştır. 
Tablo 4. ADF Birim Kök Testi Sonuçlan (İthalat)

\begin{tabular}{|c|c|c|c|c|c|c|c|}
\hline \multicolumn{4}{|c|}{ Düzey } & \multicolumn{4}{|c|}{ 1. Fark } \\
\hline & & t-Statistic & Prob. $^{*}$ & & & t-Statistic & Prob.* \\
\hline \multicolumn{2}{|c|}{$\begin{array}{l}\text { Augmented } \\
\text { Dickey-Fuller test } \\
\text { statistic }\end{array}$} & -0.958759 & 0.7561 & \multicolumn{2}{|c|}{$\begin{array}{l}\text { Augmented } \\
\text { Dickey-Fuller } \\
\text { test statistic }\end{array}$} & -6.742 .540 & 0.0000 \\
\hline \multirow{3}{*}{$\begin{array}{l}\text { Test critical } \\
\text { values: }\end{array}$} & $\begin{array}{l}\% \\
\text { level }\end{array}$ & -3.646 .342 & & \multirow{3}{*}{$\begin{array}{l}\text { Test } \\
\text { Critical } \\
\text { values: }\end{array}$} & $\begin{array}{l}\% \\
\text { level }\end{array}$ & -3.653 .730 & \\
\hline & $\begin{array}{l}5 \% \\
\text { level }\end{array}$ & -2.954 .021 & & & $\begin{array}{l}5 \% \\
\text { level }\end{array}$ & -2.957 .110 & \\
\hline & $\begin{array}{l}10 \% \\
\text { level }\end{array}$ & -2.615 .817 & & & $\begin{array}{l}10 \% \\
\text { level }\end{array}$ & -2.617 .434 & \\
\hline \multicolumn{4}{|c|}{ *MacKinnon (1996) tek yönlü p değerleri } & \multicolumn{4}{|c|}{${ }^{*}$ MacKinnon (1996) tek yönlü $\mathrm{p}$ değerleri } \\
\hline
\end{tabular}

\subsection{Optimal gecikme uzunluğu kriterlerine ilişkin bulgular}

Birim kök testlerinin ardından VAR modelini tahmin etmek üzere optimal gecikme uzunluğu araştırılmış ve sonuçlar Tablo 5 'te sunulmuştur.

Tablo 5. Optimal Gecikme Uzunluğu Kriterleri

\begin{tabular}{|c|c|c|c|c|c|c|}
\hline \multicolumn{7}{|c|}{ Lag } \\
\hline 0 & -30.60047 & NA & 0.028087 & 2.103256 & 2.195772 & 2.133414 \\
\hline 1 & 59.87999 & $163.4486^{*}$ & $0.000106^{*}$ & $-3.476129^{*}$ & $-3.198583^{*}$ & $-3.385656^{*}$ \\
\hline 2 & 63.55625 & 6.166616 & 0.000109 & -3.455242 & -2.992665 & -3.304453 \\
\hline 3 & 66.49090 & 4.543975 & 0.000118 & -3.386510 & -2.738902 & -3.175406 \\
\hline \multicolumn{7}{|c|}{ * ölçüt tarafından seçilen gecikme sırasını gösterir. } \\
\hline \multicolumn{7}{|c|}{ LR: suralı modifiye LR testi istatistiği (her test $\%$ düzeyinde) } \\
\hline \multicolumn{7}{|c|}{ FPE: Son tahmin hatası } \\
\hline \multicolumn{7}{|c|}{ AIC: Akaike bilgi kriteri } \\
\hline \multicolumn{7}{|c|}{ SC: Schwarz bilgi kriteri } \\
\hline \multicolumn{7}{|c|}{ HQ: Hannan-Quinn bilgi kriteri } \\
\hline
\end{tabular}

Optimal gecikme uzunluğunun belirlenme aşamasında tüm bilgi kriterleri, VAR modeli için 1 gecikme uzunluğuna göre tahminleme yapılması gerektiğini göstermiştir. Tahmin edilen modelin durağanlık ile ilgili bir problem taşıyıp taşımadığını belirlemek üzere AR karakteristik polinomunun ters köklerinin birim çember içerisindeki konumuna bakılmış ve Grafik 13'deki sonuçlara ulaşılmıştır. 


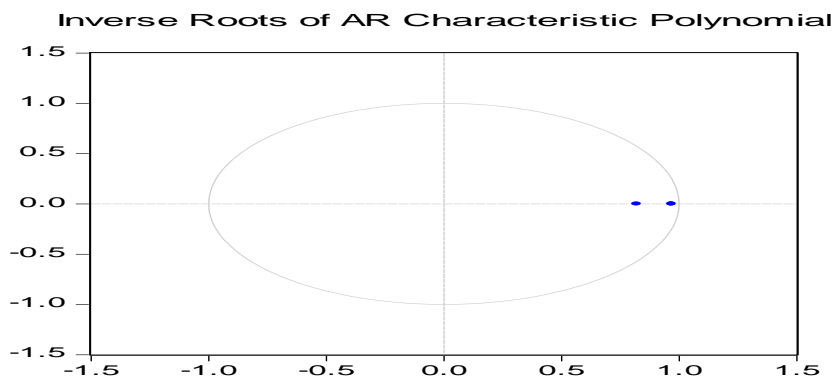

Grafik 13. AR Karakteristik Polinomunun Ters Kökleri

Grafik 13; AR karakteristik polinomuna ait ters köklerin birim çember içerisinde yer alması, tahmin edilen modelin durağanlık açısından bir sorun taşımadığını yansıtmaktadır.

\subsection{Johansen eş bütünleşme testi sonuçlarn}

Değişkenler arasındaki uzun dönem ilişki için Johansen Eş Bütünleşme Testi yapılmış ve bu testlere ilişkin bulgular Tablo 6'da verilmiştir.

Tablo 6. Johansen Eş Bütünleşme Testi Sonuçları

\begin{tabular}{|c|c|c|c|c|}
\hline \multicolumn{5}{|c|}{ Unrestricted Cointegration Rank Test (Trace) } \\
\hline \multicolumn{2}{|l|}{ Hypothesized } & Trace & 0.05 & \\
\hline No. of CE(s) & Eigenvalue & Statistic & Critical Value & Prob. ${ }^{* *}$ \\
\hline None & 0.211080 & 8.859564 & 15.49471 & 0.3785 \\
\hline At most 1 & 0.038990 & 1.272667 & 3.841466 & 0.2593 \\
\hline \multicolumn{5}{|c|}{ Trace testi 0.05 düzeyinde eş bütünleşme olmadığını gösterir. } \\
\hline \multicolumn{5}{|c|}{${ }^{*}$ Hipotezin 0.05 düzeyinde reddedildiğini gösterir. } \\
\hline \multicolumn{5}{|c|}{ ** MacKinnon-Haug-Michelis (1999) p-değerleri } \\
\hline \multicolumn{5}{|c|}{ Unrestricted Cointegration Rank Test (Maximum Eigenvalue) } \\
\hline Hypothesized & & Max-Eigen & 0.05 & \\
\hline No. of CE(s) & Eigenvalue & Statistic & Critical Value & Prob. ${ }^{* *}$ \\
\hline None & 0.211080 & 7.586897 & 14.26460 & 0.4223 \\
\hline At most 1 & 0.038990 & 1.272667 & 3.841466 & 0.2593 \\
\hline \multicolumn{5}{|c|}{ Max-eigenvalue testi 0.05 düzeyinde eş bütünleşme olmadığını gösterir. } \\
\hline \multicolumn{5}{|c|}{${ }^{*}$ Hipotezin 0.05 düzeyinde reddedildiğini gösterir. } \\
\hline \multicolumn{5}{|c|}{ "**MacKinnon-Haug-Michelis (1999) p-değerleri } \\
\hline
\end{tabular}


Trace ve max-eigen testlerine göre yenilenebilir enerji tüketimi ile ithalat arasında uzun dönemli bir bağıntı bulunmadı görülmektedir.

\section{4. İthalatın yenilenebilir enerjiye verdiği tepkiye ilişkin bulgular}

Etki-Tepki fonksiyonları yardımıyla ithalatın yenilenebilir enerji tüketimine verdiği tepki ölçülmeye çalışılmış ve ulaşılan sonuç Grafik 18' de gösterilmiştir.

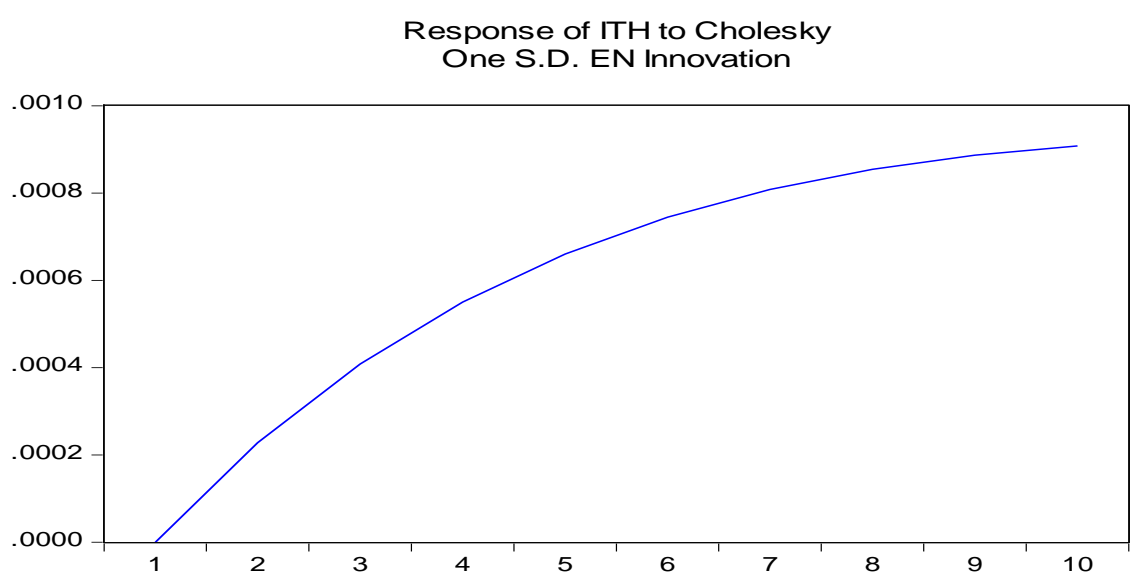

Grafik 14. Etki-Tepki Fonksiyonlar

Grafik 14'e göre; yenilenebilir enerji tüketimindeki artış ithalatın da artmasına neden olabilmektedir. Özellikle, yenilenebilir enerji teknolojilerinin belli ölçüde dışarıdan transferleri böyle bir sonucu beraberinde getirebilmektedir. Ancak son dönemlerde bu alanda yapılan önemli yatırımlar ve yürütülen çalışmalar sonucunda, teknoloji transferinin azalarak yenilenebilir enerji alanında yerli üretimin ön plana çıkmaya başladığ 1 dikkat çekmektedir.

\section{Sonuç ve Değerlendirme}

Gelişmekte olan ülkelerin karşılaştıkları en önemli problemlerden biri büyüme ve kalkınma için ihtiyaç duyduğu enerji problemidir. Enerji kaynaklarının yüksek oranda ithal edilmesi bu ekonomileri dışa bağımlı 
hale getirmektedir. Enerji konusunda dışa bağımlı olan ülkelerin ekonomileri bir tür baskı altında olması nedeniyle yerli enerji kaynaklarına geçiş yapmak ve bu geçişin hızlandırılması bu ülkeler açısından büyük önem taşımaktadır.

Dünya ekonomileri artan enerji ihtiyacının karşılanması noktasında enerji politikalarını yenilenebilir enerji kullanımının arttırılması ve bu yönünde teknolojilerin geliştirilmesi yönünde yapmaktadırlar. Yapılacak yatırımlar yenilenebilir enerji kullanımının yaygınlaşması bakımından büyük önem taşımaktadır. Enerji kaynakları bakımından büyük oranda dışa bağımlı olan ülkemizde de ithal enerji kaynaklarına olan bağımlılığın azaltılması için yerli kaynakların kullanıma hazır hale getirilmesi önemlidir. Yenilenebilir enerji kaynaklarına dayanan enerji üretiminin arttırılması bu yöndeki ar-ge'nin ve yatırımların arttırılması zorunlu kılmaktadır. Ayrıca, dünya enerji talebinin büyük oranda fosil kaynaklardan karşılanması bağlı olarak gelişen iklim değişikliklerinin önüne geçilmesi adına yenilenebilir kaynaklara yönelimin ve yatırımların arttırılması atılması gereken zorunlu bir adım olarak değerlendirmek mümkündür.

Gelişmek için üretmeye, üretmek için enerjiye ihtiyacı olan ülkemiz bu ihtiyacını karşılamak için ithalat yoluna gitmektedir. Enerjiye olan talep gün geçtikçe artmakta bu duruma paralel bir şekilde Türkiye' nin enerjide dışa bağımlılığı her geçen gün artmaktadır. Ülkemizde petrol ve doğalgaz ithalatı önemli bir kalem olması enerjiyi, cari dengenin bozulmasında en önemli etken yapmaktadır. Buna bağlı olarak da ekonomik kaynakların önemli bir kısmı bu yönde harcanmaktadır. Dolayısıyla da son dönemlerde ekonomide yaşanan cari dengesizliğin enerji açığı olarak yorumlanmasina neden olmaktadir.

Türkiye'nin cari açığının enerji açığı olarak değerlendirilmesi yenilenebilir enerji kaynaklarının önemini ortaya koymaktadır. Bu açıdan yenilenebilir enerji tüketiminin arttırılmasını ülkemizin ithalatına etkisinin olup olmadığı, varsa hangi düzeyde olduğunu incelenmiştir. Söz konusu incelemede, Türkiye'de 1984-2017 yıllarına ait verilerle yenilenebilir enerji tüketimi ile ithalat arasındaki ilişki VAR analizi ile test edilmiştir. Çalışmada VAR analizi kapsamında ilk aşamada serilerin durağanlıkları Augmented Dickey Fuller (ADF) Testi ile test edilmiştir. Durağanlık testi sonucunda her iki serinin de düzeyde birim kök içerdiği anlaşılmıştır. Bu 
durumda da serilerin birinci farkları alınmış ve sonrasında serilerin birinci farklarının durağan olduğu görülmüş̧ür.

Değişkenler arasında VAR modelinin kurulabilmesi amacıyla gecikme uzunluğunun belirleyebilmek için test yapılmıştır. Test sonucu doğrultusunda Var modeli kurulurken optimal gecikme uzunluğu 1 olarak belirlenmiştir. Ayrıca, değişkenler arasındaki uzun dönemli ilişkiyi belirlemek üzere Johansen Eş Bütünleşme testi yapılmıştır. Trace ve maxeigen testlerine göre yenilenebilir enerji tüketimi ile ithalat arasında uzun dönemli bir bağıntının bulunmadığı sonucu elde edilmiştir.

Etki-Tepki fonksiyonları kullanılarak ithalatın yenilenebilir enerji tüketimine verdiği tepki ölçülmüş ve Etki-Tepki fonksiyonlarından elde edilen grafiğe göre; yenilenebilir enerji tüketimindeki artışın ithalatın da artmasına neden olduğu görülmüştür. Özellikle yenilenebilir enerji teknolojilerinin belirli oranda dışarıdan alınıyor olması bu sonucu beraberinde getirebilmektedir. Ancak, son dönemlerde yürütülen çalışmalar ve yapılan yatırımlar, teknoloji transferini azaltarak yenilenebilir enerji alanındaki ilerlemeler neticesinde diş ticaret dengesinin daha fazla iyileşeceği beklenmektedir. 


\title{
EXTENDED ABSTRACT
}

\section{The Effect of Renewable Energy Consumption on Import in Turkey}

\author{
Erdal Arslan - Aysun Solak \\ Selçuk University
}

Due to the oil crises in 1973 and 1974, the contraction in energy supply revealed the importance of energy and energy supply continuity and directed the world to search for alternative energy sources. On the other hand, in addition to the energy supply security problem, climate change caused by fossil fuels, unsustainable nature due to high cost reasons, the non-renewable nature of fossil fuels, unbalanced distribution and limited reserves are considered to be insufficient to meet the energy demand in the long term. In the years left behind, countries have sought alternative energy sources due to the mentioned problems and tried to produce policies for the diversification of energy resources. In this process, they focused on the efforts to bring renewable energy sources into use, and the years 2000s have been the years in which the importance given to alternative energy sources and the investments made have increased. In today's world, significant developments have taken place in many countries, and a significant portion of these countries' energy demands are met by renewable energy sources.

Today, energy is now the most important element of political and economic superiority in the international arena. Therefore, the importance of providing energy supply security, sustainability and ease of access means a priority for the countries. Increasing the consequences for the use of renewable energy sources for energy-importing developing countries such as Turkey are much more distinct significance. In this respect, the development of technologies for increasing the use of renewable energy resources is important for the sustainable economic development of countries. 
One of the most important problems faced by developing countries is the energy problem for growth and development. The high import of energy resources makes these economies dependent on foreign countries. Due to the fact that the economies of countries dependent on foreign countries in energy are under some kind of pressure, it is important for these countries to make the transition to domestic energy resources and accelerate this transition.

Our country, which needs energy to produce, to produce for development, goes to import way to meet this need. demand for energy increasing day by day and, depending on these conditions, Turkey's dependence on foreign energy is increasing with each passing day. The fact that the importation of oil and natural gas is an important item in our country makes energy the most important factor in the deterioration of the current balance. Accordingly, a significant portion of economic resources are spent in this direction. Therefore, the current account balance in the economy has been interpreted as energy deficit. The evaluation of Turkey's energy deficit of the current account deficit reveals the importance of renewable energy sources. In this respect, in this study, it is examined whether increasing the consumption of renewable energy has an effect on the importation of our country and the level of it. In the study, the relationship between renewable energy consumption and imports with data for 19842017 years in Turkey has been tested with VAR analysis.

In order to establish the VAR model between the variables, the test was carried out to determine the length of the delay. The optimal delay length is set to 1 when installing the Var model according to the test result. In addition, Johansen Cointegration test was used to determine the longterm relationship between the variables. According to Trace and maxeigen tests, there is no long-term relationship between renewable energy consumption and imports. According to the results of the Johansen cointegration test, there is no long-term connection between the variables. Reaction-Response functions showed that the increase in renewable energy consumption also increased imports. As a result, although renewable energy technologies, which were transferred from outside to a certain extent, led to this increase, it can be said that the recent studies and important investments made, and the decrease in technology transfer, domestic production started to come to the fore in the field of renewable energy. 
The investments to be made are of great importance for the use of renewable energy. In our country, which is highly dependent on foreign sources in terms of energy resources, it is important to make the domestic resources ready for use to reduce the dependence on imported energy resources. Increasing the energy production based on renewable energy resources necessitates the increase of $\mathrm{R} \& \mathrm{D}$ and investments in this direction. In addition, it is possible to consider increasing the tendency towards renewable resources and increasing the investments in order to prevent the climate changes due to the world energy demand being met by the fossil resources in large part.

\section{Kaynakça / References}

Apergis, N. ve Danuletiu, D. C. (2014). Renewable energy and economic growth: Evidence from the sign of panel long-run casuality. International Journal of Energy Economics and Policy, 4(4), 578-587.

Apergis, N., ve Payne, J. E. (2010). Renewable energy consumption and growth in Eurasia. Energy Economics, 32(6), 1392-1397.

Bhattacharya, M., Parmati, S. R., Öztürk, İ. ve Bhattacharya, S. (2016). The effect of renewable energy consumption on economic growth: Evidence from top 38 countries. Applied Energy, 162, 733-741.

Bilginoğlu, M. A. ve Dumrul, C. (2012). Türk ekonomisinin enerji bağımlılığı üzerine bir eş bütünleme analizi. Journal of Yaşar University, 4392-4414.

BP. (2017). Statistical review of world energy. (BP, Düzenleyen). 12 13, 2017 tarihinde https://www.bp.com:https://www.bp.com/content/dam/bp/en/corporate/pdf/energy-economics/statistical-review-2017/bp-statistical-review-of-world-energy-2017-full-report.pdf adresinden alınd1.

BP. (2018). BP Global. 11 07, 2018 tarihinde www.bp.com: https://www.bp.com/en/global/corporate/energy-economics/statistical-review-of-world-energy/primary-energy.html adresinden alınd. 
Brini, R., Amara, M. ve Jemmali, H. (2017). Renewable energy consumption, international trade, oil price and economic growth interlinkages: The case of Tunisia. Renewable and Sustainable Energy Reviews, 76, 620-627.

DEK-TMK. (2018, 01 29). http://dektmk.org.tr. 01 29, 2018 tarihinde http://dektmk.org.tr/upresimler/turkiye-enerji-piyasasinin-gorunumu.pdf adresinden alındı.

Demir, M. (2013). Enerji ithalatı cari açık ilişkisi VAR analizi ile Türkiye üzerine bir inceleme. Akademik Araştırmalar ve Çalışmalar Dergisi, 5(9), 2-27.

Doğan, İ. ve Gürbüz, S. (2017). Enerji fiyatlarının dış ticaret açı̆̆ı üzerindeki rolü: Doğrusal olmayan ilişkinin analizi. Ömer Halisdemir Üniversitesi İktisadi ve İdari Bilimler Fakültesi Dergisi, 10(2), 81-90.

Durğun, B. ve Durğun, F. (2018). Yenilenebilir enerji tüketimi ile ekonomik büyüme arasında nedensellik ilişkisi: Türkiye örneği. International Review of Economics and Management(IREM), 6(1), 1-27.

Enerji ve Tabii Kaynaklar Bakanlığ1- Enerji Isşleri Genel Müdürlüğü. (2016). Enerji Isşleri Genel Müdürlüğü. http://www.eigm.gov.tr/trTR/Denge-Tablolari/Denge-Tablolari adresinden alınmıştır.

Enerji ve Tabii Kaynaklar Bakanlığı(ETKB);Türkiye Taşkömürü Kurumu(TTK). (2017, Mayıs). 2016 Yılı Taşkömürü Sektör Raporu. 12 20, 2018 tarihinde: http://www.taskomuru.gov.tr/file/duyuru/TTKGM_Sektor_Raporu_2016.PDF adresinden alındi.

Enerji ve Tabii Kaynaklar Bakanlığı-Enerji İşleri Genel Müdürlüğü. (2015). Enerji İşleri Genel Müdürlü̆̈̈̈. http://www.eigm.gov.tr/trTR/Denge-Tablolari/Denge-Tablolari adresinden alınmıştır.

Erdoğan, S., Dücan, E., Şentürk, M. ve Şentürk, A. (2018, Nisan). Türkiye'de yenilenebilir enerji üretimi ve ekonomik büyüme ilişkisi üzerine ampirik bulgular. Ömer Halisdemir Üniversitesi İktisadi ve İdari Bilimler Fakültesi Dergisi, 11(2), 233-246.

ETKB. (2018). Enerji ve Tabii Kaynaklar Bakanlığı. 2018 tarihinde www.enerji.gov.tr. adresinden alındi.

IEA. (2018). International Energy Agency. 11 08, 2018 tarihinde www.iea.org. adresinden alınd1. 
Khobai, H., Abel, S. ve Roux, P. L. (2017). A review of the nexus between energy consumption and economic growth in the brics countries. Nelson Mandela Metropolitan University, 17, 82462. 12 05, 2018 tarihinde https://mpra.ub.uni-muenchen.de/82462/ adresinden alındı.

Khobai, H., Kolisi, N., Moyo, C., Anyikwa, I. ve Dingela, S. (2017). Renewable energy consumption and unemployment in South Africa. Nelson Mandela University, 12, 83160. https://mpra.ub.unimuenchen.de/83160/1/MPRA_paper_83160.pdf adresinden alınmıştır.

Önder, H., ve Polat, A. (2018, Mart). Enerji tüketiminin GSYIHH ile ilişkisi: OECD ülkeleri panel veri analizi. Marmara İktisat Dergisi, 2(1), 105116.

Sancar, C. ve Polat, M. A. (2015). Türkiye'de ekonomikbüyüme, enerji tüketimi ve ithalat ilişkisi. Gümüşhane Üniversitesi Sosyal Bilimler Elektronik Dergisi, 12, 416-432.

SETAV. (2018, 01 16). https://www.setav.org/. 01 16, 2018 tarihinde http://www.setav.org/2016da-enerji/ adresinden alınd1.

TEİAŞ. (2018). Türkiye Elektrik İletim A.Ş. 11 07, 2018 tarihinde https://www.teias.gov.tr/tr/i-kurulu-guc-0 adresinden alınd1

Türkiye İstatistik Kurumu. (2018). TÜIKK. 12 20, 2018 tarihinde http://www.tuik.gov.tr/UstMenu.do?metod=temelist adresinden alınd 1

Uysal, D., Yilmaz, K. Ç. ve Taş, T. (2015). Enerji ithalatı ve cari açık ilişkisi: Türkiye örneği. Muş Alparslan Üniversitesi Sosyal Bilimler Dergisi, 3(1), 63-78.

\section{Kaynakça Bilgisi / Citation Information}

Arslan, E. ve Solak, A. (2019). Türkiye' de yenilenebilir enerji tüketiminin ithalat üzerindeki etkisi. OPUS-Uluslararası Toplum Araştırmaları Dergisi, 10(17), 1380-1407. DOI: 10.26466/opus.521269 